\title{
CONVERSATIONAL IMPLICATURE OF INDONESIAN STUDENTS IN DAILY CONVERSATION
}

\author{
Annisa Martini \\ Department of English Education, Faculty of Teachers Training and Education, University of Kuningan \\ Email: annisamartini@gmail.com
}
APA Citation: Martini, A. (2018). Conversational implicature of Indonesian students in daily communication. Indonesian EFL Journal, 4(1), 93-100. DOI: 10.25134/ieflj.v4i1.889.

\begin{abstract}
The research examined conversational implicature of Indonesian students of English Education Department in University of Kuningan in the daily conversation. The reason of choosing this topic was based on the problem in which people frequently produce utterances which are not informative or provide less or too much information as required in their daily conversation. This qualitative research used observation and recording to collect the data needed. As result, this research found 80 utterances indicating conversational implicature which consist of 32 utterances $(40 \%)$ belonging to generalized conversational implicature and 48 utterances $(60 \%)$ belonging to particularized conversational implicature. In conclusion, the utterances contain two types of conversational implicature and its function in conversation causing different assumption based on Tsuda's theory such as violation of Grice's cooperative principle, power and solidarity and joking indirect conversation. However, the functions itself are influenced by interpretation of the researcher as the listener or a reader.
\end{abstract}

Keywords: conversational implicature, daily conversation, functions of conversational implicature, Indonesian students

\section{INTRODUCTION}

Conversational implicature is the basic assumption in conversation in which the participants are adhering to the cooperative principle and the maxims (Yule, 1996). Maxim is an assumption to use utterance in information that provided by speaker or writer. Grice (1975) considers these maxims as unstated assumptions in conversations. The assumption is then elaborated into four subprinciples of maxim, there are Maxim of Quantity, Maxim of Quality, Maxim of Relevant, and Maxim of Manner. First, in maxim of quantity, people are required to give contribution as informative as is required and do not make their contribution more informative than is required. Second, maxim of quality asks people to make their contribution that is ture, do not say what they believe to be false, and do not say that for which they lack adequate evidence. Third, in maxim of relevant, people are required to make their contribution which is relevant. Last, in maxim of manner, people are required to avoid obscurity of expression, avoid ambiguity, be brief, and be orderly.

On the other hand, Yule (1996) states that the expectations of cooperative principle does not have an appropriate what is being uttered. This statement describes the implicature that the speaker flouts the Grice's maxim in an utterance. Conversational implicature is the basic assumption in conversation is that, unless otherwise indicated, the participants are adhering to the cooperative principle and the maxims (Yule, 1996, p. 44). When the speakers are giving the message to the interlocutor, the listeners can conclude what the speakers said.

Conversational implicatures have two kinds; generalized conversational implicature and particularized conversational implicature. Yule (1996) explains that "a generalized 
conversational implicature occurs when no special knowledge is required in the context to calculate the additional conveyed meaning" (p. 45). In this kind of implicature, the speaker gives the utterance, but the listener just respond a part of the utterance. In addition, Yule (1996) states such inferrences are required to work out of the delivering meanings which result from particularized conversational implicature. The inferrence of utterance totally is not going on the context.

Tsuda (1993) explains that functions of conversational implicature is a framework of indirectness conversation that has three functions of indirectness conversation. There are violation of Grice's cooperative principle, power and solidarity, and joking as indirect expression. Accordingly, the study focuses on analyzing the types of conversational implicature made by Indonesian students in their daily conversation and the function constructed constructed by Indonesian students in their conversational implicature.

\section{METHOD}

This qualitative research involved 16 English department students to be the participants. The research concerns in natural context such as when the students use their language in their daily conversation. The data were collected through observation and recording. It purposes to analyze how the conversational implicature is conducted in natural context and determine the types of conversational implicature and its function.

The researcher then presents 40 data selected from the recording in which 20 data belonging to generalized conversational implicature and 20 data belonging to particularized conversational implicature. In addition, the researcher analyzed the function of conversational implicature. The steps in analyzing the data include transcribing the recording, identifying the data transcription, coding on the list where it is indicated as the type of conversational implicature, making the occurrences precentage of the types of conversational implicature, and describing the function of the utterance that has conversational implicature.

To calculate the percentage of the Frequency of conversational implicature, the researcher uses the following formula by Subana (2000):

$$
\begin{aligned}
& \text { FK rel }=\frac{F K}{\Sigma F} \times 100 \% \\
& \text { FK rel }=\text { Frequency of relative cumulative (the } \\
& \text { result of precentages) } \\
& \text { FK = Frequency of cumulative (the number of }
\end{aligned}
$$

\section{RESULTS AND DISCUSSION Types of conversational implicature}

From six recordings, the researcher found 80 utterances belonging to the two types of conversational implicature, namely generalized conversational implicature and particularized conversational implicature. The percentage of each type of conversational implicature is presented in the table below.

Table 1. Types of Conversational Implicature Identified

\begin{tabular}{cccc}
\hline No. & Types of Conversational Implicature & Frequency & Precentage (\%) \\
\hline 1. & Generalized Conversational Implicature & 32 & $40 \%$ \\
2. & Particularized Conversational Implicature & 48 & $60 \%$ \\
& Total & 80 & $100 \%$ \\
\hline
\end{tabular}

From the table, it can be seen that there are found 80 data of conversational implicature consisting of 32 data or $40 \%$ belonging to generalized conversational implicature and 48 data or $60 \%$ belonging to particularized conversational implicature. 


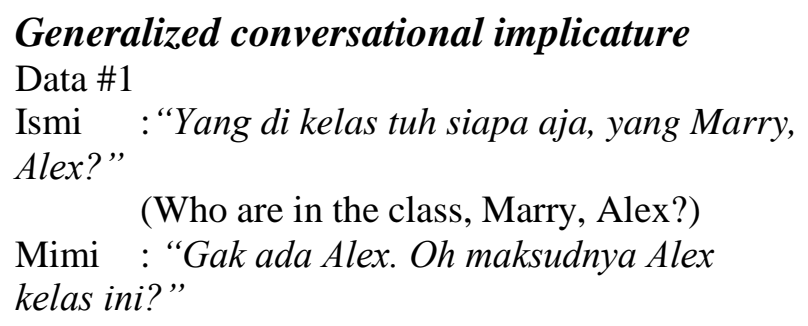
this class?

In the second floor, Ismi asked Mimi to call Marry and Alex who would be the participants of her research. But, in the middle of conversation, Mimi asked Ismi's feeling to Alex.

The conversation between Ismi and Mimi can be categorized as generalized conversational implicature because it does not have special background knowledge about its context. Ismi asked about a student named Alex. Mimi firstly said that there is no student named Alex, but she then realized that there is a student named Alex in that class.

Nevertheless, Mimi suddenly asked Ismi's feeling to Alex. The function of "Yes. Do you like Alex?" is to make a tease for Ismi or Mimi wants to know Ismi's feeling to Alex. This has flouted the maxim of quantity because Mimi gives more information than it is required.

\footnotetext{
Data \#2

Ismi : "Cik atuh Marry mau panggil sini dong. Mau ada perlu sih sebenernya mau penelitian."

(Please, call Marry. I need her for my research)

Mimi : "Kenapa gak ke kita aja gitu, kita kan pinter."

(Why don't do it to us, we are smart.)

Ismi : "Boleh boleh, ke kalian aja ya.

Penelitiannya meneliti short story, kalau

kalian mau..."

(Well, sure. I'll involve you in this research. The research is going to observe about short story, if you want...)

(Context)

Ismi was excited that Mimi has offered herself to be volunteer of Ismi's research and Ismi was little
}

bit happy because Mimi wanted to be her participant.

The utterance "Well, sure. The research is going to observe about short story, if you want..." includes as generalized conversational implicature because Ismi's utterance does not have background knowledge about Mimi's statement. The statement explains that Mimi and her friend are smart too, but Ismi did not know it. So, Ismi was very excited when Mimi offered herself to be the participant in Ismi's research. Furthermore, this is the flout of maxim quantity because Ismi added more information that is not required by Mimi. Indeed, for the function of this impicature is that Ismi was very excited when heard Mimi requested to be a participant of her research although Ismi did not ask Mimi before.

Data \#3

Mimi :"Enggak mau lah teh ke Marry aja sama Ratna." Ratna)

(I don't want to do that, just ask Marry and Ismi : "Ia nanti panggilin dong Marry dulu aja Marry yah?"

(Context)

(Please call Marry then, okay?")

Ismi asked Mimi to call Marry since Mimi do not want to be the participant in her research.

The underline statement is included into generalized conversational implicature because when Mimi said that she would like call Marry and Ratna, Ismi only needed Marry who would be participant and she ignored Ratna as an option in Mimi's statement. The function of implicature is Ismi asked Mimi to call Marry because she just needed Marry who is one of the smartest students in the class. Indeed, for Ismi's utterance, it includes the flout of maxim quantity because Ismi makes a contribution in her utterance more than as requested.

Data \#4

Cathy : "He'eh sih. Nanyanya yang banyak. Nanya apa aja. Terus ngasih apa teh gitu ke pihak anaknya enggak?" 
(He'eh. Asking more questions. Asking anything. Do you want to give them something?)

Alin : "Nanti atuh itu mah." (We'll see.)

Cathy :"Tapi mau kamu?" (But, do you want to do that?)

Alin : "Kayanya mau da objeknya juga cuma satu. Kalau misalkan objek akunya banyak anak-anak di kelas paling ke gurunya, ini mah objeknya cuma satu ya mungkin ke gurunya."

(Probably, I will do it because it is the only one object. If my object is a lot of children in the class, it will be conducted to the (Context) teacher, but this is the only one.)

The underline gives the explanation of Alin's utterance. Alin attempted to explain about how the way to interview to the teacher or students.

The underlined utterance means that Alin gives the example about for whom she will give the gift after doing observation. The function of "I think I will do it because it is the only one object. If my object is a lot of children in the class, it will be conducted to the teacher, but this is the only one" is generalized conversational implicature for the reason that essentially Cathy does not need Alin's details. Indeed, it indicates as flout of maxim quantity because Alin has added information more than Cathy's assumption such as Alin informs the participants who will be given a gift in supporting her observation.

\section{Data \#5}

Alin : Laporan PPL pada udah ya kalian?"

(Have you finished the report of PPL?)

Cathy :"Udah."

(Yes, I have.)

Dinda :"Tapi yang softcopynya aku belum." (But, I haven't done the softcopy.)

(Context)

Dinda's uttearance illustrates that she had accomplished the report, but she had not already collected her task in softcopy.

Dinda says "But, I haven't done the softcopy" in the conversation showing Dinda's utterance is generalized conversational implicature because the utterance refers to Alin's question. Alin asks to her friends about PPL report, but then Dinda suddenly says she has not collected the softcopy report yet. In the conversation, Alin has known about the report in softcopy and hardcopy but she does not put the option because they have understood the context. Dinda says "But, I haven't done the softcopy" because she had already finished and collected the hardcopy, not the softcopy. This utterance then flouts the maxim of manner.

\section{Particularized conversational implicature}

Data \#6

Ismi : "Udah ngobrol sama Alex sih, Alex mau. Nah Marry mau enggak?"

(I have talked to Alex, and he agreed. How about you?)

Marry : "Ia, yah mau teh." (Yes, I will.)

Ismi : "Baik banget, ih dia baik banget."

(Context) (Very kind, she's very kind.)

Ismi gave the compliment to Marry because Marry had been ready to be a participant in her observation.

The utterance "Very kind, she's very kind" is the particularized conversational implicature because the utterance works out of the context. When Marry said that she was ready to help Ismi but Ismi gave the respond about Marry's character which it absolutely does not have relation to Marry's utterance. It has implicit with what was conveyed in the message. It flouted the maxim of relevant because Ismi has added the information that is not relevant and it was not informative for the answer. Moreover, the function of the implicature that Ismi intended to persuade and gave the expression of compliment for Marry so that Marry would like to help her.

Data \#7

Ismi : "Ini ada short storynya. Itu dari bahasa Inggris nanti ditranslatein ke bahasa Indonesia nanti kirim lewat e-mail aja." 
(This is the short story. It is written in English so that you should translate it into bahasa and send the result via e-mail.)

Marry : "Iya."

$$
\text { (Yes.) }
$$

Ismi : "Wah, bapaknya udah masuk..." (Wah, the lecturer has entered...)

Marry :"Ini buat Marry sendiri gitu?" (Is this for me?)

(Context)

Ismi wanted to close the conversation because there was a lecturer who come in the class.

Ismi's utterance comprised the particularized conversational implicature because Ismi's utterance has worked out of the context. For instance, the utterance "Wah, the lecturer has entered..." has flouted the maxim of relevant because it has conveyed the meaning that is not informative and related within the context being spoken. When they were talking about Ismi's observation, Ismi responded about the lecturer who come into the class to teach B class. The function of "Wah, the lecturer has entered..." is Ismi wanted to close the conversation for the reason that there is a lecturer who come to the class and she was hurry up to end the explanation. Nevertheless, Marry still asked her about some pieces of paper in her hands.

Data \#8

Alin : "Yaiya atuh pas ngerecord kan interview."

(Yes, I was interviewing when I did the recording.)

Cathy : "Mmm, ya diini direkam."

(Mmm, yes it was recorded.)

Alin : "Nanti diketik lagi. Ia, kan Cuma ada 3 orang."

(Then it will be typed again. Yes, there were 3 persons.)

(Context)

Alin told Cathy the next step after interviewing and then informing the number of her participant.

Alin's utterance attempts to explain that she will transcribe after recording the conversation. The utterance "Then will typed again. Yes, there are 3 person" belongs to particularized conversational implicature because when Cathy's statement just " $M m m$, recorded", Alin responds out of Cathy's statement. Moreover, the utterance "Then will typed again. Yes, there are 3 person" means that Alin has known what should she do in her observation. She emphasizes that she will be able do the next step and also informs the number of the participant that is not required by Cathy as the speaker. The utterance then flouts the maxim of relevant because what is being spoken is not relevant with Alin's response.

Data \#9

Cathy : "Atuh berarti itu kamu ngeluarin uang banyak ya nanti tuh?"

(It means that you will spend more money for it?)

Alin : "Ih, nanti mah simple aja ngasihnya kalau mau mah, anaknya baik itu mah kaya cewek." (It's so simple to give him, he is kind as a girl.)

Cathy : "He'em."

(Context) (He'em.)

The utterance above demonstrates that Alin will give anything if the participant also wants to support her observation.

The utterance "Ih, it's so simple to give him, he is kind as a girl" is particularized conversational implicature because Alin's response towards Cathy's question does not relate to what Cathy has said. Cathy asks Alin about "It means that you will spend more money for it?" and Alin answers by giving statement that work out of Cathy's assumption like adding a gender. For example Alin makes the participant similar with a girl. It should not be put on her response because Cathy does not need the information. Subsequently, this flouts maxim of relevant as it does not relate with Cathy's utterance.

Data \#10

Alin : "Ah, males ah."

(Ah, upsetting.)

Cathy : "Pas aku kesini baru masuk?" the room?) 
(Context)

Cathy asked Alin about her guidence with the supervisor and she saw Alin who was being lazy because she had been waiting for a long time.

The particularized conversational implicature signed by the utterance "When I come in, has she just come into the room?" because it works out of the context when Alin says that she get upset to wait for several minutes, suddenly Cathy asks a question to her. The question does not relate with Alin's statement. This utterance then flouts the maxim of relevant because Cathy's utterance is not relevant with Alin's utterance.

\section{Functions of conversational implicature Violation of Grice's cooperative principle} The first function of conversational implicature in Students' daily conversation is violation of Grice's cooperative principle. In conversational implicature, the violation is used to imply the cooperative principle of Grice's theory (Tsuda, 1993).

Data \#11

Alin : "Uh dia mah kita dimana dia mah udah selesai. Kita mah masih dijudul dia mah udah dipembahasan. Si Ismi juga udah beres ya, apa lagi penelitian?"

(Uh, he had finished. When we are still discussing the title, he has been in the discussion. Has Ismi finished, or is she still doing her research?)

Cathy : "Lagi." (On going.)

Alin : "Eh Cathy Cathy, kamu nengok cik iya biar ibunya tahu ada kita. Jadi, ada kamu nanti ada aku juga nanti ibunya teh..." (Eh Cathy, you see the lecturer so that she knows we are here. So, here is you and me..)

Cathy : "Tapi tadi pas aku kesini teh ya ngelihatin aja aku. Dianya tuh lagi fokus sama Eli dianya curhat bukan bimbingan."

(But, when I come in, she looks at me. But she focuses on Eli who is telling not guding.)

The underline utterance, Alin orders Cathy to get up from her chair and walks into the lecturer's room then she only sees outside and probably Alin is being lazy that she does not want to get the room because she has been waiting for a long time.

\section{Power and solidarity}

According to Tsuda (1993), power and solidarity is "indirectness sometimes damages communication when it is used only for selfish aims to manipulate others. In a society where people are sensitive to the rank order of the people in a group as in Japan, indirectness is often employed by people of higher status to control people of lower status."

Data \#12

Alin : "Aku pernah nyobain apapun."

(I have ever tried anything.)

Dinda : "Jaba lipstickna."

(Especially the lipstick.)

Alin : "Liptatto teh zaman dulu." (Liptatto in the past.)

Alin's utterance informs that she had tried liptatto as one kind of familiar lipstick ever in the past, she used to buy every new lipstick especially for liptatto. Alin uses the language to show up that she is a girl who loves the cosmetics.

\section{Joking indirect expression}

They are consoled by the language that is being delivered so the people can smile easier. It is usually used in natural context such in informal situation when the people are talking with their close friend (Tsuda, 1993). Data \#1

Ismi : "Yang di kelas tuh siapa aja, yang Marry, Alex?”

(Who are in the class, Marry, Alex?)

Mimi : "Gak ada Alex. Oh maksudnya Alex kelas ini?" this class?)

(There is no Alex. Oh, you mean Alex in

Ismi : "He'eh kelas ini."

(He'eh this class.)

Mimi : “Ada, iya. Teteh suka sama Alex?"

(Yes. Do you like Alex?)

The function of the underlined statement is to make a tease to Ismi or Mimi 


\section{Annisa Martini}

Conversational implicature of Indonesian students in daily communication

wanted to know Ismi's feeling towards Alex. The utterance can make them laugh because there is a little bit tease that refers to Ismi.

\section{CONCLUSION}

This research investigates conversational implicature of Indonesian Students in University of Kuningan. After analyzing the data transcription, the researcher found 80 utterance belong to the two types of conversational implicature such generalized conversational implicature and particularized conversational implicature. Of 80 utterances, 32 utterances $(40 \%)$ belong to generalized conversational implicature and 48 utterances (60\%) belong to particularized conversational implicature. From the precentage, it can be seen that the dominant of conversational implicature in natural context of Indonesian students is particularized conversational implicature with the number of occurrences is $48(60 \%)$.

Meanwhile, in terms of the function of conversational implicature, the research revealed three function of conversation, there are violation of Grice's cooperative principle, power and solidarity, and joking indirect expression. The function itself can be influenced by the situation in communication. However, the researcher concludes that the function depends on interpretation of the researcher and the speakers or the listeners who are participants in a conversation. So, the conversational implicature can be occured in a conversation especially in natural context. Therefore, there has no principle to use the language widely, because as many as people use the language appropriate with their needs.

\section{REFERENCES}

Grice, H. P. (1975). Logic \& conversation. Barkeley: University of California.

Harmer, J. (2008). The practice of English language teaching. Cambridge: Longman.

Inayati, A., Citraresmana, E., \& Mahdi, S. (2014). Flouting maxims in particularized conversational implicature. Journal of Language Learning and Applied Linguistics World, 6(3), 53-61.

Kreidler, C. W. (1998). Introducing Englsih semantics. New York: Routledge.

Leech, G. N. (1983). Principle of Pragmatics. London: Longman.

Levinson, S. N. (1983). Pragmatics. New York: Cambridge University Press.

Lodico, M. G., Spaulding, D. T., \& Voegitle, K. H. (2006). Methods in educational research. San Fransisco: Jossey-Bass.

Schiffrin, D., Tannen, D., \& Hamilton, H. E. (2001). The handbook of discourse analysis. Oxford: Blackwell Publisher.

Subana. (2000). Statistik pendidikan. Bandung: Pustaka Setia.

Tsuda, S. (1993). Indirectness in discourse: What does it do in conversation? Journal of Intercultural Communication Studies, 3(1), 63-74.

Yule, G. (1996). Pragmatics. New York: Oxford University Press. 